\title{
Relationships between capabilities-strategy alignment and accountability-emphasis in government business enterprises
}

\author{
Seng Cheaseth, $\mathrm{PhD}$ (Corresponding author) \\ Associate Dean, Faculty of Business and Economics \\ Director, Institute of Customs, Taxation and Border Management \\ Paññāsāstra University of Cambodia \\ Contact details: Phone: (855) 017465738 Email: sengcheaseth@puc.edu.kh
}

Received: July 01, 2011 Accepted: July 09, $2011 \quad$ DOI: 10.5296/jpag.v1i1.769

\begin{abstract}
This study introduces a new research perspective to the investigation of factors affecting management's attention to the rendering of their organisation's managerial and public accountabilities. It draws on management studies of the fit between organisational strategy-types and capabilities and extends this literature to a new organisational context of government-owned business enterprises (GBEs) that act as fully competitive profit-making enterprises, but are made strongly accountable to the government minister, the parliament and the public.

Sets of capabilities-strategy alignments are modelled, including prospecting GBEs with technology strengths, defender GBEs with market-linking capabilities and analyser GBEs with a balance of capabilities. These sets are then assessed in terms of their consequences for the emphasis given by management to processes and systems for discharging the GBE's accountability outcomes. Data is collected through a questionnaire to senior managers of 141 GBEs in Australia.

The findings are mostly consistent with prior studies conducted in private sector companies, even though strategy-capabilities alignments are related to accountability rather than financial performance. The findings provide insights to GBEs' management and relevant government ministers concerning the continuing need to appropriately align strategies and capabilities of GBEs and the consequences of such alignment for the rendering of accountability.
\end{abstract}

Keywords: Managerial accountability, public accountability, organisational capabilities, strategic-type, government-owned enterprises 


\section{Introduction}

Statutory authorities and trusts of governments in Australia were re-constituted during the 1980 s and 1990 s as profit-making corporations under national competition laws. They became known as government business enterprises (GBEs). They were provided with considerable management autonomy in which their CEO and board of directors could set strategic directions and make resource management choices. Nevertheless, they remained wholly-owned by government, and the relevant government minister, in effect, retained the power of their sole shareholder. While acting as fully competitive profit-making enterprises, they were also made strongly accountable to the government minister, the parliament and the public (Bottomley, 2001; Barret, 2000; Halligan and Horrigan, 2005; Wettenhall, 1998). GBEs are, thus, controlled under a structure that places high expectations on their ability to succeed in a competitive market by returning regular dividends from profits to government, and at the same time meeting high demands on their accountability to the minister, parliament and the public. Accountability is viewed in terms of management's obligation to set and report on processes and outcomes, especially associated with the enterprise's objectives, relevant government policies and customer-needs.

The modern operating arrangements for GBEs have been the subject of much debate. A major focus of political and media attention has been on the potential effectiveness of management in driving commercial performance while upholding their enterprise's community service obligations (CSOs). Thynne (1998b) and Thynne and Wettenhall (2004) express concern that the manager-shareholder structure of GBEs can both enhance and constrain their operations and thus the extent to which their objectives can be obtained. They contend that government policy controls specifically imposed on GBEs affects not just their actual performance but also the means by which performance is formally assessed. This issue is not new since it dates back to Seidman's (1954) theory of evolution of the public trading enterprise organisation. The move to full autonomy is favoured in term of achieving commercial objectives; however it is not favoured in term of accountability. The issue of meeting multiple accountabilities and at the same time striving for financial efficiency is a primary concern of most public sector entities according to Barret (2000).

The current study will empirically investigate the manifestation of the way GBE management fulfils one of its primary functions, namely, the aligning of its organisation's capabilities with its strategies. From there, the study will then empirically investigate whether the nature of this alignment relates to a second primary function of GBE management, namely, meeting pressures for multiple accountabilities.

\section{Research Question, Objectives and Significance of the Study}

The research question addressed in this study is set in the context of for-profit business enterprises with autonomous management, but with accountability demands from government as their sole shareholder. The question is stated as follows: does the alignment of strategies and capabilities of a GBE (as shaped by its management) have a relationship with the effectiveness of its discharge of accountabilities (as sought by its shareholder-government and the public)? 
The objectives of the study are:

(1) To extend the literature on the inter-relationships between strategic-type and organisational capabilities into a new organisational context of government-owned and controlled business. Prior modelling and testing of companies' strategies-capabilities-matches has not been extended beyond the private sector.

(2) To provide evidence on the effect of alternative mixes of capabilities-strategies alignments of GBEs on the extent of attention given by management to policies and processes for discharging organisational accountabilities to the government-owner and the public. In prior studies, evidence on the effectiveness of types of strategies-capabilities matches has been provided in terms of performance measures such as profit, return on assets, sales growth and customer-retention; but not on the rendering of accountabilities.

(3) To draw conclusions about the extent to which alternative capabilities-strategies alignments relate to accountability-emphasis within GBEs, in order to provide insights of relevance for management practice and government policy-makers.

Further elaboration is given on the points mentioned in the above objectives that make this study significant. First, the modelling of concepts used in private sector and public sector studies can be brought together in the unique context of GBEs where management needs to balance accountability and profitability (Thynne, 1998; Bottomley, 2001). Previous studies on the relationship between the strategies-capabilities match and performance have been in the context of profitability and related financial performance measures in privately-owned businesses (Smith et al., 1986; Conant et al., 1990; Snow and Hrebiniak, 1980). But the aligning of strategies and capabilities is an equally primary management function in GBEs where the performance of this function needs to be assessed in terms of accountability outcomes as much as profitability.

Second, the findings from the study can provide new insights for government ministers, the board of directors and executive management in making strategic and resourcing decisions that can affect the GBE's accountability-related performance. It can help these decision-makers to find and maintain the preferred alignment between their enterprise's range of capabilities and chosen strategy-type, particularly in facilitating a trend towards a 'public interest' approach to accountability in response to criticisms of the narrow performance orientation of public sector management practices that has emerged (e.g., Lapsley, 1999; Goddard, 2005). A growing accountability trend in the public sector, which would apply to GBEs, is to ensure that the wider public interest is not glossed over or neglected when it conflicts with a narrow financial performance orientation.

\section{The context of GBEs and their accountability}

Government business enterprises are wholly-owned organisations of federal, state or territory governments that have been corporatized and commercialised, but not privatised. Governments create GBEs when they want to conduct some form of commercial enterprise at arm's length from the usual government departmental structures and processes (Bottomley, 2000). In Australia, the two distinct industry-types of GBEs are public trading enterprises and 
public financial enterprises (McDonough, 1998). The public trading enterprises are enterprises other than financial service providers that provide or administer products and services for commercial return (e.g., energy, water, ports, rail, and ferries). Public financial enterprises, on the other hand, are public enterprises that operate commercially as financial intermediaries (e.g., insurance, funds management, superannuation and land release management).

The current operating environment of GBEs has mainly reached the third and final stage of Seidman's (1954) stages of GBE evolution. This stage consists of rules and procedures that allow for a balance of managerial autonomy against the demand of political control and accountability (Thynne, 1998). Regulatory aspects that restrict management's operating autonomy concern, first, any community service obligations (CSO) imposed by a minister (Uhrig, 2003). A CSO requirement is specifically stated in GBE's respective enabling Act. Second, GBEs need to comply with reporting requirements. They need to report to the relevant Department of Treasury and their responsible minister(s) in a form of a statement of corporate intent, which includes their corporate plan and half yearly and annual report (Queensland Treasury, 2006; Tasmania Treasury \& Finance, 1995; NSW Treasury, 2005). Their annual report will be tabled in parliament.

GBEs consist of three legal forms. The three forms are commercial statutory corporation, company state-owned corporation (SOC), and a direct government company incorporated under the Corporation Act 2001. The first form is incorporated under a specific Act of Parliament. The latter two represent government-controlled corporations that are similarly established by registering with the Australian Securities and Investment Commission as a company under the Corporation Act 2001. In all legal forms, the management and ownership are separated, although the relevant minister will have a close monitoring role on management as it carries out the day-to-day operations, particularly any implementation of direct government policies.

A central feature that draws GBEs into the web of public sector accountability is their 'publicness', due to the fact they are ultimately owned by the public through government. This ownership requires that they be controlled and called to account in ways that enable them to meet their responsibilities to the government, parliament and the public (Thynne, 1998; Thynne and Wettenhall, 2001; Aharoni, 1981). Hence, GBEs are likely to be subject to various accountability dimensions including political, managerial, public and fiduciary accountability (Othman \& Taylor, 2008). Fiduciary accountability is of less concern for GBEs than other public sector entities in terms of normal day-to-day operating activities, because GBEs are not dependent on government budget for operating funds. In contrast, public accountability is likely to be important for GBEs. The inclusion of CSOs requires GBEs to be accountable to the public for the performance of the CSOs provided. Since GBEs operate like competitive private sector businesses in providing goods and services to the public, their public accountability will expect to have a strong customer-focus, even when CSOs are not imposed upon them. Turning to the dimension of managerial accountability, the underlying corporatization and commercialisation of GBEs means that management is to be accountable for the economy, efficiency and effectiveness with which the GBEs meets their operating 
objectives.

According to McDonough (1998) there is usually built into GBEs' enabling Acts an accountability of management for financial performance. Such managerial accountability requires GBEs to regularly report and justify to government the extent of efficiency in the use of resources for the delivery of outputs, and effectiveness of management in achieving pre-set outcomes for projects and programs.

While there is a considerable body of literature on accountability and its dimensions in government departments and agencies and local government authorities, research on accountability in GBEs has been minimal. One exception is Luke (2008) who studied accountability in New Zealand state owned enterprises (SOE) through a combination of in-depth interviews with executives and secondary data. Her findings are somewhat consistent to Sinclair (1995) as she found that accountability of GBEs can be seen as "similar to a web, encompassing numerous and complex dimensions" (Luke, 2008, p. 24). Nevertheless, she concludes that three dimensions of accountability are clearly presented in the executives' discussions. First, political accountability, in context of SOEs, is seen as an upward reporting responsibility to relevant ministers and to oversight bodies. It involves due approval processes, where ministerial approval is required for major development and investment projects. The executives who were interviewed mentioned that ministers expect a "no surprises policy" (Luke, 2008, p. 17). Third, public accountability is found by Luke, 2008 ) to be a significant factor for SOEs according to the interviewed executives. It is found to involve a customer-focus and an extending SOEs' responsibilities beyond their mandated areas to social and environmental responsibilities. Lastly, managerial accountability is seen by the SOE executives in Luke's (2008) study to be a central performance responsibility because of its emphasis on commercial or financial success of the SOE. As cited in Luke (2008), one executive stated that:

I think the biggest risk is not being able to recoup your investment...since our SOE framework is about being able to justify the investment... [and] we need a return that is above market (p.16).

\section{Strategic type and performance}

Miles and Snow's (1978) much cited 'strategic typology' provides a grand theory of typologies that can, supposedly, be generalised to all organisations, according to Doty and Glick (1994). Miles and Snow portray the type of strategy developed by a firm in terms of solutions by management to the overall interaction among entrepreneurial problem(s), engineering problem(s) and administrative problem(s). When the management chooses to enter into an entrepreneurial position it creates an entrepreneurial problem(s) to be solved. The engineering problem(s) and administrative problem(s) are to be recognised when selecting an entrepreneurial position (Kald et al. 2000). This is the adaptive nature of Miles and Snow's strategic typology, where the engineering and administrative problems and solutions are adaptive to the selected entrepreneurial position. From such reasoning, Miles and Snow identify four strategic positions for firms that exist within an industry, which they term the prospector, analyser, defender and reactor. The main difference among these 
strategic types is the rate of change in the entrepreneurial position or organisation domain (Zahra and Pearce, 1990; Miles et al. 1978).

As explained by Contant et al. (1990), Miles and Snow's prospector and defender organisations are considered to be on the opposite ends of a product domain continuum. The entrepreneurial problems and solutions of prospector organisations indicate that they are the first mover in product development in the market. This suggests that prospector organisations can compete on the basis of product differentiation. The engineering problems and solutions support this position by suggesting prospector organisations have flexibility and innovation, multiple technologies and pushing-edge capabilities. At the opposite end, defender organisations have a narrow and carefully focused product domain. The engineering problems and solutions suggest that these organisations should focus on cost efficiency. Thus, defender organisations are less active in product research or responsive to market change. They compete on a low-cost basis (Slater and Narver, 1993). The analyser organisations are located in between the prospectors and defenders and thus share both of prospectors' and defenders' characteristics. The reactor organisations have an unsystematic strategic pattern and thus are consider as a residual strategy. It is difficult to determine the competitive basis of this strategic type.

Miles and Snow (1978) suggested that the three 'archetypal' strategic types (prospectors, analysers and defenders) should all perform well, and should out-perform reactors due to the latter's lack of a stable strategy. But this original model did not explore under what circumstances the archetypal strategic types would be the highest in performance, nor was the definition of performance made clear. Subsequent empirical tests of the Miles and Snow framework by Conant et al. (1990) and Desarto et al. (2005) have measured its performance consequences. Conant et al.(1990) defined performance based on competitive capability theory. Desarto et al. (2005) measured the performance of strategic-types on the basis of profit, return on assets, market share, sales growth and customer retention. These studies confirm that the three archetypal strategic types perform equally well on average.

\section{Strategy- capabilities alignment and performance}

Doty and Glick (1994) also approach Miles and Snow's typology from a middle range theory perspective. In this perspective, each of the three archetypal strategic types contains sets of engineering and administrative solutions. This middle range viewpoint suggests that each strategic type should align with a set of distinct organisational capabilities. Taking the more general perspective of the resource-based view (RBV), Song et al. (2007) argue that capabilities do not improve productivity of the organisation on their own. Capabilities need to be aligned with the right strategic position to enable exploitation of benefits and, in turn, generate superior value the organisation. Hence, some capabilities are preferred to others depending on the strategy chosen by the organisation (Song et al., 2007).

Organisational capabilities (hereafter known as capabilities) are defined in marketing and strategic management literatures as "complex bundles of skills and accumulated knowledge, exercised through organisational processes, that enable firms to coordinate activities and make use of their assets" (Day, 1994, p. 38). The concept of capabilities is used 
interchangeably with the concepts of distinctive competencies (Snow and Hrebiniak, 1980), competitive devices (Davig, 1986) and sources of advantage (Day and Wensley, 1988).

Capabilities can be divided into several categories. Smith et al. (1986) provide a categorization for organisational general capabilities, including general management, marketing, R\&D engineering and production, and accounting and finance. Snow and Hrebiniak's (1980) distinctive competences are similar to Smith et al. (1986) with the addition of distribution, legal affairs and personnel. These capabilities are of a general category and apply to all types of organisations. Hitt and Ireland (1985) identifies 55 different distinctive competence activities within functional areas. O'Regan and Ghobadian (2004) through interviews with six managing directors and two employer representatives provide a list of generic capabilities of small manufacturing firms. Their capabilities range from advertising and promotion to offering consistent quality.

In an important addition to the above capabilities, Day (1994) provides two sets of strategically-related capabilities, namely inside-out capabilities (I-O) and outside-in capabilities (O-I). The I-O (also referred to by Song et al. (2007) and Desarto et al. (2005)) as 'technology capabilities') are found to be important capabilities for organisations that compete on the basis of low cost. Alternatively, the O-I (also referred to as 'market-linking capabilities' by Song et al. (2007) and Desarto et al. (2005)) are found to be used by market-oriented or product-differentiation types of organisations. The capabilities listed under the I-O category are consistent with Smith et al. (1986) and Snow and Hrebiniak (1980). By comparison, the $\mathrm{O}-\mathrm{I}$ capabilities are market-sensing in nature (understand the target market(s) and competitors' capabilities). They consist of customer-linking capability (creating and managing durable customer relationship) and channel-bonding capability (creating durable relationships with channel members such as suppliers and customers). These types of O-I capabilities are also known as distinctive marketing competencies (Conant, Mokwa, and Varandaranjan, 1990) and marketing capabilities (Vorhies, Harker, and Roa, 1999; Vorhies and Harker, 2000).

Returning to the issue of relationships between strategic types and organisational capabilities, empirical studies have sought evidence on the ways certain organisational capabilities and management's selected entrepreneurial position align with Miles and Snow's strategic types. In other words, such studies look at what capabilities each strategic type should possess to enable it to achieve its selected products or services' market domain. In addition, some of these studies look at the relative performance among key sets of strategy-capabilities matches.

Snow and Hrebiniak (1980) look at relationships between a set of distinctive competences and each of Miles and Snow strategic types in the context of more highly entrepreneurial industries. Their findings about the relationships between capabilities and strategic-type suggest that prospectors possess market research, product research and development, and basic engineering. In contrast, defenders have production, engineering and financial management capabilities. This is consistent with the original suggestions of Miles and Snow. Nevertheless, Snow and Hrebiniak (1980) did not find any distinct pattern of capabilities in 
the analysers, as they could not be distinguished from the prospectors and defenders. They concluded that analysers have both prospectors' and defenders' characteristics. The reactors did not show any distinctive pattern of capabilities. In effect, their findings suggest that a prospector needs to have market research, product research and development and basic engineering capabilities to achieve superior performance. In contrast, a defender must have production, engineering and financial management capabilities to succeed.

Others studies look at similar relationships and test similar propositions. The main differences among them are context of study and type of capabilities. Davig (1986) looks at small manufacturing firms and employs capabilities of competitive prices, on-time delivery, product quality, unique product and customer services. He found that prospectors concentrate on price competitiveness and product uniqueness, while defenders focus on on-time delivery and product quality. This finding is supportive of Miles and Snow in that product uniqueness requires flexible and innovative technology and product quality requires a focus on core technology and product expertise. In another study, Smith et al. (1986) focus on electronic manufacturing firms and broad capabilities that resemble Miles and Snow's entrepreneurial and engineering solutions. Their cluster analysis shows each strategic type has the capabilities characteristics that are portrayed by Miles and Snow.

In a more recent and comprehensive study, Di Beneditto and Song (2003) employ four sets of capabilities (i.e., Day's (1994) inside-out capabilities, outside-in capabilities, information technologies capabilities and marketing capabilities. Their findings suggest that prospectors have information technology and inside-out capabilities, and the defenders have marketing and outside-in capabilities. The analysers possess both the prospectors' and defenders' characteristics. These result are consistent with more recent studies by Song et al. (2007) and Desarbo et al. (2005). Song et al. (2007) employ technology, IT, market-linking and marketing capabilities and find that prospectors have greater technology, and IT capabilities than defenders, whereas defenders have greater market-linking and marketing capabilities then prospectors.

Generally, the findings of Song et al. (2007), Desarbo et al. (2005) and Di Beneditto and Song (2003) give support to a resource-based view (RBV) of strategies and capabilities alignments. As suggested by Song et al. (2007), the RBV reasons that defenders, in order to maintain a secure niche in a stable product or service area, must quickly anticipate changes in the market and their customers' needs. Thus developing a greater degree of market-linking and marketing capabilities than others is required. On the other hand, defenders have no need to develop technology and IT capabilities to the extent required by prospectors, since they are not innovative, nor do they continuously develop new products or services as with case with prospectors.

Some of the above studies on strategy-capabilities alignment extend their findings to consider performance consequences. Song et al. (2007) find that a good fit between strategic position and capabilities leads to superior financial performance. They find that firms' alignment between the prospector strategic-type and technology/IT capabilities is positively related to firms' financial performance. On the other side, they find that defender-type firms have a 
positive relationship with financial performance when they possess market-linking and marketing capabilities. Two other studies look at similar relationships in different contexts. These studies are conducted in Spanish hospitality firms (Garrigos-Simon, Marques, and Narangajavana, 2005) and Australian exporting manufacturing firms (Shoham, Evangelista, and Albaum, 2002). Both studies provide results that are consistent with the predictions of the RBV and middle range theories of Miles and Snow's strategic typology, and they extend the generalizability of this strategic-capabilities-performance framework to various contexts.

\section{Development of hypotheses}

As reviewed in section 5, there have been consistent prior findings from several industries and countries about the existence of an identifiable fit between particular strategy-types and capabilities. This study seeks to extend the evidence to a context of government business enterprises that operate in a competitive environment and have considerable managerial autonomy, as has been the case for other strategies-capabilities studies to date. But, unlike prior studies, these enterprises are also wholly government owned and face political and public accountability demands. Based on the literature of the most widely established fits, it is hypothesised that:

H1: Prospector-type GBEs have the greatest technology capability, whereas defender-type GBEs have the greatest market-linking capabilities.

Turning to the performance consequences of these different strategy-capabilities alignments, it was concluded from a review of prior studies in section 5 that prospector firms with technology strengths do well on financial performance, and defender firms with marketing skills also do well on financial performance. Analyser firms with balanced capabilities in both technology and marketing also do well on financial performance. This study seeks to test these relationships by substituting managerial and public accountability for financial performance. Management's ability to be answerable for a set of accountabilities to government and the public will be dependent on the suitability of organisational strategies and capabilities it operates with. Increases in entrepreneurial problems, for example, could make accountability to a minister or accountability for delivery of quality services to the public more problematic than would be the case for financial performance. To test the robustness of the established set of strategy-capabilities alignments in relation to their consequences for accountability, the following three hypotheses are put forward:

H2: $\quad$ Prospector-type GBEs with stronger technology capability provide a greater managerial and public accountability-emphasis.

H3: Defender-type GBEs with stronger market-linking capability provide a greater emphasis on managerial and public accountability.

H4: Analyzer-type GBEs with a stronger combination of both technology and market-linking capabilities provide a greater emphasis on managerial and public accountability.

Consistent with prior studies (Song et al., 2007; Zahra and Pearce, 1990; Shoham et al., 2002) 
the current study makes no attempt to investigate the capabilities-strategy alignment of reactor firms and its impact on accountability-emphasis.

\section{Model specification}

Following Song et al. (2007) the study uses multiple regressions instead of one-way analysis of variance that has been commonly used in other studies, to analyse the relationships between capabilities and strategies alignments and accountability-emphasis. The empirical models are given as follow:

$\mathrm{ACCTY}=\beta^{0}+\beta^{1}$ ORGSIZE $+\beta^{2}$ LEGALFM $+\beta^{3}$ INDUSTRY $+\beta^{4} J U R I S D I C+\varepsilon$

$\mathrm{ACCTY}=\beta^{0}+\beta^{1}$ ORGSIZE $+\beta^{2}$ LEGALFM $+\beta^{3}$ INDUSTRY $+\beta^{4}$ JURISDIC $+\beta^{5}$ PTA +

$\beta^{6} D M A+\beta^{7} A S A+\varepsilon$

where

ACCTY = accountability emphasis in the managerial and public dimensions;

PTA $=$ prospector strategic position alignment with technology capabilities;

$\mathrm{DMA}=$ defender strategic position alignment with market-linking capabilities alignment;

ASA $=$ analyser strategic position alignment with the of average of market-linking and technology capabilities;

ORGSIZE= organisation size;

LEGALFM = legal form of organisation;

INDUSTRY $=$ nature of industry operations of the organisation;

JURISDIC $=$ government jurisdiction of the organisation.

\section{Sampling}

A census of GBE is conducted to determine the total number of GBEs across all government jurisdictions. The result provides a total of $160 \mathrm{GBEs}$, but $16 \mathrm{GBEs}$ are found to be unsuitable for this study. The excluded GBEs comprise of 11 entities of a non-commercial nature, 3 GBEs no longer owned by their respective governments as of January 2008 and 2 GBEs with incomplete management structures (one does not have a management team and the other has no board of directors). Therefore, the GBE population applicable to this study is 144 , and the sample used in the study is 141 GBEs, equivalent to $97 \%$ of the applicable population. There were a further three GBEs excluded because of their annual reports were not accessible publicly.

Turning to the collection of primary data, the survey questionnaire was sent out in two stages. 
The first stage was in August 2008 and 423 survey questionnaires were sent to the 141 GBEs. Following common practices used in survey questionnaire data collection, three survey questionnaires were sent to three senior managers in a GBC. At the end of this first period, 94 responses- a $21 \%$ response rate were received. A total number of 3 respondents did not identify their organisations, thus an alignment with annual report data could not be made. This left 91 identifiable responses, representing 71 GBEs- approximately $50 \%$ of the sample applicable for data analysis. In order to maximise the coverage of number of GBEs in the responses, the follow up questionnaires were sent to GBEs that did not response in the first stage. A total of 95 questionnaires were sent out to 31 GBEs in September 2008. At the end of the period 22 responses- a $23 \%$ response rate were received. These responses represent 17 GBEs. Thus, at the end of the two periods a total of 115 responses, representing 91 GBEs- $64 \%$ of the sample were available for data analysis. The data will be analysed using SPSS software.

\section{Measurement of Variables}

The scales for the four main variables to be tested in this study, ACCTY, technology capabilities (TECH), market-linking capabilities (MKL) and Strategic-type, are given in the Appendix as extracts from the questionnaire.

The dependent variable, organisational accountability-emphasis (ACCTY), is limited in scope to the dimensions of managerial and public accountabilities. Managerial and public accountabilities are faced by all forms of GBEs and are present across a common range of GBE performance situations. Dimensions concerned with the political chain of accountability and fiduciary compliance requirements are excluded from the ACCTY measure because they will different considerably between GBEs of different operating forms and in different jurisdictions. The scale items chosen for this ACCTY variable are drawn from prior empirical studies on dimensions of accountability (Stewart, 1984; Taylor and Rosair, 2000; Sinclair, 1995; Luke, 2008) authoritative guidelines and normative discussion on accountability of GBEs (Bottomley, 2001; Department of Treasury and Finance, 1998; Funnell and Cooper, 1998; Thynne, 1998), and a textual analysis of sample of GBEs' annual reports. In addition, the ACCTY scales are developed base on two interviews with senior executives of GBEs. There are eight scales and the senior managers were asked to indicate their agreement with the wording of these items. The validity and reliability of this 8-item measure of ACCTY are tested with factor analysis and Cronbach's alpha- internal reliability in Table 1. Two items were excluded from the construct because they did not load on the first factor; 
Table 1: Managerial and Public Accountability (ACCTY): Validity and Reliability Tests

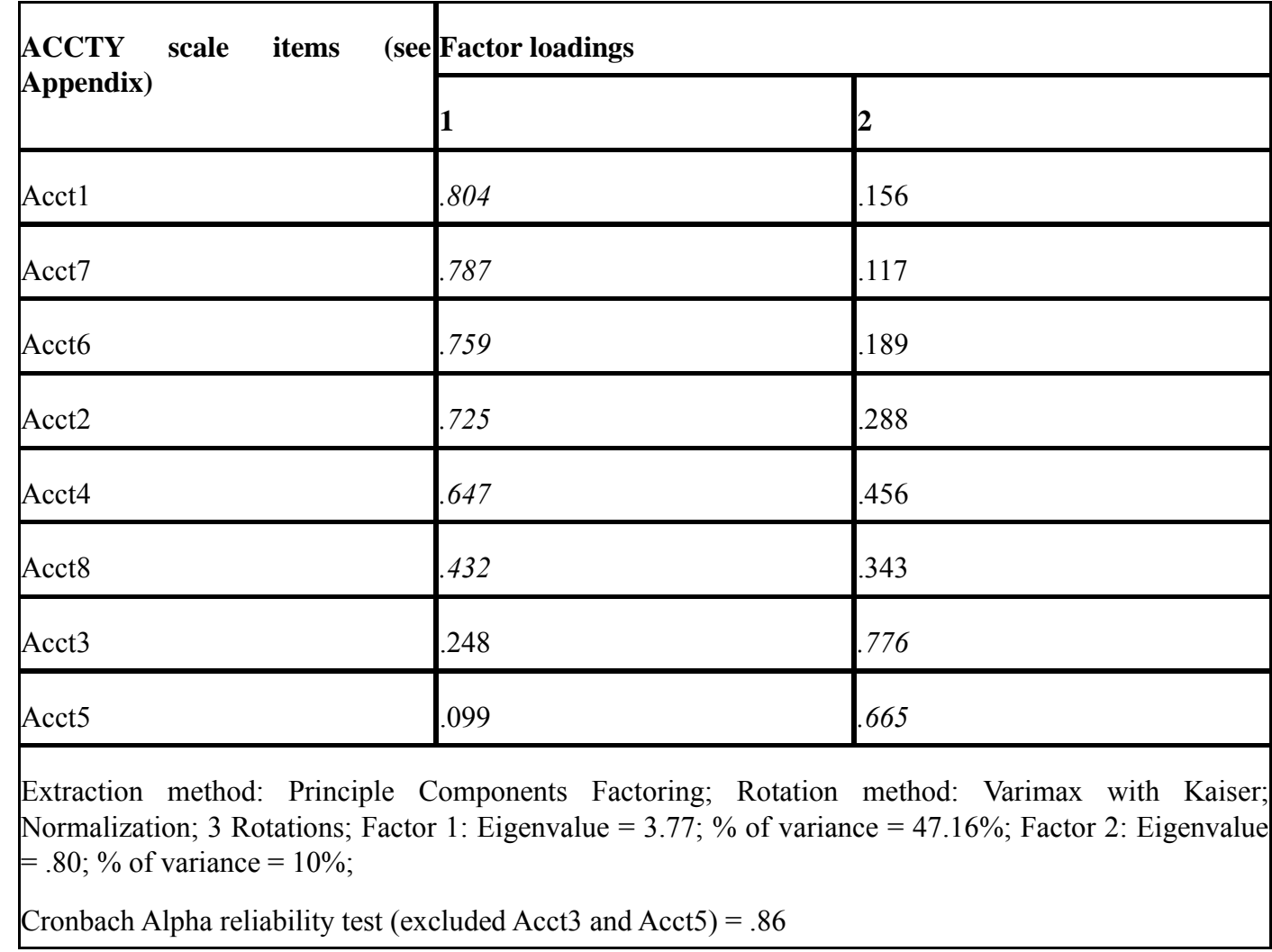

Turning to the independent variables, GBEs' strategic positions are identified via self-selecting. Refer to the Appendix. The managers are asked to indicate a strategic position that closely assembles their current strategy-type. The instrument on strategic-types is drawn from Snow and Hrebiniak's (1980) paragraph approach to measuring Miles and Snow's (1978) strategic typology. The data on strategic-type is entered as a dummy variable. For example, with a prospector GBE, the prospector strategic position will have a value of 1 and the other strategic-types will be given a zero value.

In relation to the measurement of organisational capabilities, only technology and market-linking capabilities are included. Refer to the Appendix. These two types of capabilities are deemed to have most relevance to the context of GBEs. The areas of operation of GBEs typically fall into two types. There are those that need advanced technology (e.g., clean and waste waters management (water corporations), port management (port corporations/authorities), energy generation, distribution and retailing management (energy corporations)); or there are those that need market-linking capabilities (e.g., public buses, trains and ferries operations (transport corporations), holiday resort (tourism corporations/authorities), financial management and investment (treasury corporations, fund management corporations, superannuation and lending institutions). Prior studies also conduct selective investigation on firms' capabilities (Song et al., 2007; Snow and Hrebiniak, 1980; Conant et al., 1990; Zahra and Pearce, 1990). The five scale items of both the 
technology capability variable and the market-linking capability variable are developed base on Day (1994), Di Beneditto and Song (2003) and Song et al. (2007). In addition, they are reviewed against findings from a textual analysis of a sample of GBEs' annual reports and interviews with senior executive of GBEs. This process has helped to ensure that the questionnaire is context relevant. The validity and reliability of both capabilities are tested with factor analysis and Cronbach alpha. Results are given in Table 2.

Table 2: Technology and Market-linking Capabilities: Validity and Reliability Tests

\begin{tabular}{|c|c|}
\hline Technology Capabilities & Factor \\
\hline Product Services Transformation Process & .814 \\
\hline Monitor Predict Technological Changes & .810 \\
\hline Technology Development and Innovation & .804 \\
\hline Financial Management Capability & .558 \\
\hline Cost Management Capability & .514 \\
\hline \multicolumn{2}{|c|}{$\begin{array}{l}\text { Extraction method: Principal Axis Factoring; } 1 \text { factor extracted; } 7 \text { iterations; Eigenvalue }=2.57 ; \% \\
\text { of variance }=51.49 \% \text {; Cronbach Alpha reliability test }=.833\end{array}$} \\
\hline Market-linking Capabilities & Extraction \\
\hline Customer linking Capability & .789 \\
\hline Creating Supplier Durable Relationship Capability & .666 \\
\hline Channel Bonding Capability & .663 \\
\hline Ability to Retain Customers & .631 \\
\hline Market Sensing Capability & .618 \\
\hline
\end{tabular}

\section{Results of Hypothesis Tests}

\subsection{Strategic-types and accountability}

In section 4, it was indicated that Miles and Snow (1978) believed that their three 'archetypal' strategic types (prospectors, analysers and defenders) should all perform well, and should out-perform reactors due to the latter's lack of a stable strategy. Subsequent studies such as Desarto et al. (2005), confirm that the three archetypal strategic types perform equally well on average when performance of a firm is measured in terms of a range of financial ratios. Does this conclusion hold when strategy-types are evaluated on the basis of a GBEs discharge of its managerial and public accountabilities? The results in Table 3 reveal that the archetypal strategy-types (defender, prospector and analyser) are very similar in terms of their 
consequences for the management emphasis on accountability within the organisation. Their means are between 5.39 and 5.36. In contrast, the reactor-type is significantly lower in accountability-emphasis.

Table 3: Differences between mean of accountability for strategic-types

\begin{tabular}{|l|l|l|c|}
\hline Strategic-type & \multicolumn{2}{|l|}{$\begin{array}{l}\text { Accountability-emphasis Std. Dev. } \\
\text { Mean }\end{array}$} & $\begin{array}{r}\text { One-way ANOVA } \\
\text { Difference between means } \\
\text { F-value; Sig. }\end{array}$ \\
\hline Defender & 5.36 & .722 & \multirow{2}{*}{ F $=8.172 ;$} \\
Prospector & 5.39 & .537 & \\
\hline Analyser & 5.36 & .501 & \\
\hline Reactor & 3.84 & 1.565 & \\
\hline
\end{tabular}

\subsection{Strategy-capabilities alignment}

Turning to the relationship between the capabilities and strategic type, Hypothesis 1, was developed in section 6, suggests that a prospector-type GBEs aligns with technology capability, whereas defender-type GBEs aligns with market-linking capabilities. The results in Table 4 reveal that, indeed, prospector-type GBEs have the highest technology capability strength, whereas defender-type GBEs have the highest market-linking capability strength. Hence, H1 is supported.

Table 4: Relationships between strategy-type and Capability strengths

\begin{tabular}{|c|c|c|c|}
\hline Capability & Strategic-type & $\begin{array}{l}\text { Mean of the capability' } \\
\text { strength }\end{array}$ & $\begin{array}{l}\text { One-way ANOVA } \\
\text { F Stat. and Sig. }\end{array}$ \\
\hline \multirow[t]{4}{*}{ Technology } & Defender & 4.87 & \multirow{4}{*}{$\begin{array}{l}F=4.459 \\
\text { Sig. }=.005\end{array}$} \\
\hline & Prospector & 5.04 & \\
\hline & Analyser & 4.64 & \\
\hline & Reactor & 3.85 & \\
\hline \multirow[t]{4}{*}{ Market-linking } & Defender & 5.24 & \multirow{4}{*}{$\begin{array}{l}F=9.091 \\
\text { Sig. }=.000\end{array}$} \\
\hline & Prospector & 4.93 & \\
\hline & Analyser & 4.84 & \\
\hline & Reactor & 3.45 & \\
\hline
\end{tabular}

10.3 The effects on accountability of alternative strategy-capabilities alignments

Studies on the performance of firms that adopt certain strategy-capabilities alignment were reviewed in section 5. For example, Song et al. (2007) find that a good fit between strategic position and capabilities leads to superior financial performance. Hypotheses 2 to 4 were developed to extend the testing of different sets of strategy-capabilities alignment to their consequences for the emphasising of managerial and public accountability in GBEs. The sets of alignments are constructed as individual strategic type matches with its respective 
capabilities, which is in line with the approach taken by Song et al. (2007). First, dummy variables are assigned to each strategic type. For example, prospector strategy GBE is assigned with value of 1 if that GBE classified it strategy as prospector, otherwise 0 . Second, the match is determined by multiplying the strategic types with their determined alignment of capabilities (Table 4). Table 5 presents the multiple regressions analysis of control variables and matches variables on accountability-emphasis by GBEs. The model's explanatory power is high as reflected in its adjusted-R-squared of .529. Further, multicollinearity is not present as revealed in the relatively normal tolerance and VIF numbers. To avoid potential multicollinearity due to the inclusion of all three types of match in one model, the data for these capabilities were mean-centred. Next, the control variables of GBE organisational size, legal form, industry category and government jurisdiction are all found to be not significantly related to ACCTY. Therefore, stratification of the data is not needed.

In terms of the impacts of the matches on accountability-emphasis (ACCTY), Table 5 indicates that they are highly significant and positively related to ACCTY. Therefore, these results lead to the acceptance of $\mathrm{H} 2, \mathrm{H} 3$ and $\mathrm{H} 4$.

Table 5: Regression of Strategy-Capabilities Alignments on Accountability

\begin{tabular}{|c|c|c|c|c|c|c|c|}
\hline \multirow{2}{*}{ Model } & \multicolumn{2}{|c|}{$\begin{array}{c}\text { Unstandardized } \\
\text { Coefficients }\end{array}$} & \multirow{2}{*}{\begin{tabular}{|c|}
$\begin{array}{c}\text { Standardized } \\
\text { Coefficients }\end{array}$ \\
Beta
\end{tabular}} & \multirow{2}{*}{ t } & \multirow{2}{*}{ Sig. } & \multicolumn{2}{|c|}{ Collinearity Statistics } \\
\hline & B & $\begin{array}{l}\text { Std. } \\
\text { Error }\end{array}$ & & & & Tolerance & VIF \\
\hline (Constant) & 5.540 & .236 & & 23.462 & .000 & & \\
\hline ORGSIZE & 7.388E-9 & .000 & .011 & .165 & .870 & .940 & 1.064 \\
\hline LEGALFM & -.034 & .069 & -.037 & -.492 & .624 & .746 & 1.341 \\
\hline INDUSTRY & .000 & .161 & .000 & -.003 & .997 & .890 & 1.124 \\
\hline JURISDIC & -.018 & .022 & -.059 & -.817 & .416 & .783 & 1.278 \\
\hline PTA & .532 & .119 & .296 & 4.456 & .000 & .938 & 1.066 \\
\hline DMA & .554 & .180 & .201 & 3.085 & .003 & .978 & 1.023 \\
\hline ASA & .567 & .108 & .352 & 5.236 & .000 & .914 & 1.094 \\
\hline
\end{tabular}

\section{Conclusions and Implications}

This study introduces a new research perspective to the investigation of factors affecting the management's discharge of their organisation's accountabilities. It draws on the management and marketing literature to replicate the modelling of the alignment between the organisational strategies-capabilities, and then investigates the consequences that this positioning of the organisation can have on the attention given by management to organisational accountabilities. The study relates broad constructs that have been applied in competitive private enterprise environments to a construct that has been applied in the public 
sector environment. This has been possible because GBE's provide the setting for the study. GBEs are organisations that operated in a nexus between private sector market conditions and public sector ownership and oversight conditions.

The evidence provided in this study from questionnaire data gives a range of conclusions that extend prior findings. Conclusions are drawn that Miles and Snow's strategy typology is identifiable amongst GBEs; that archetypal strategy-types (defender, prospector and analyser) are very similar in terms of being better for the attention given by management to the rendering of accountability by GBEs whereas reactor-type is not; that organisational capabilities in the broad areas of I-O or technology and O-I or market-linking tend to line up with particular strategy-types in GBEs; and that identifiable matches of strategies-capabilities have a significant positive effect on the emphasising of managerial and public accountabilities in GBEs.

The findings have implications for both executive management and boards of GBEs, for government ministers in their capacity as representative of the sole government-shareholder of GBEs, and for the public receiving the services of GBEs. By being cognizant of the continuing need to appropriately align strategies and capabilities of GBEs and being mindful of the consequences of such alignment for the rendering of accountability, strategy-formulators and policy-makers in GBE management and wider government can better play their role in a GBE's success.

\section{Acknowledgement}

The authors would like to thank participants in the $32^{\text {nd }}$ Annual Congress of the European Accounting Association and accounting academic at Deakin University's School of Accounting, Economics and Finance for their constructive comments on the research models and analysis framework of the paper.

\section{References}

Aharoni, Y. (1981). 'Performance Evaluation of State-Owned Enterprises: A Process Perspective'. Management Science, Vol. 27 No. 11, pp. 1340-1347.

Aiken, L. S., and West, S. G. (1991). Multiple regression: Testing and Interpreting Interactions. Newbury Park. CA: Sage Publications.

Bottomley, S. (2001). 'Government Business Enterprises and Public Accountability through Parliament', Department of the Parliamentary Library, Research Paper No. 18.

Conant, J. S., Mokwa, M. P., and Varandaranjan, P. R. (1990). 'Strategic Types, Distinctive Marketing Competences: A Multiple Measures-Based Study'. Strategic Management Journal, Vol. 11, pp. 365-383.

Davig, W. (1986). 'Business Strategies In Smaller Manufacturer Firms'. Journal of Small Business Management, Vol. 24 No. 1, pp. 38-46.

Day, G. S. (1994). 'The Capabilities of Market-Driven Organisations'. Journal of Marketing, 
Vol. 58 October, pp. 37-52.

Day, G. S., and Wensley, R. (1988). 'Assessing Advantage: A Framework for Diagnosing Competitive Superiority'. Journal of Marketing, Vol. 52 April, pp. 1-20.

Department of Treasury and Finance. (1998). 'Corporate Governance Handbook for Government Business Enterprise'. Commercialisation and Financing Branch-Department of Treasury and Finance. Tasmania Government December, 1998.

Desarbo, W. S., Di Benedetto, A., Song, M., and Sinha, I. (2005). 'Revisiting The Smiles and Snow Strategic Framework: Uncovering Interrelationships Between Strategic Types, Capabilities, Environmental Uncertainty, and Firm Performance'. Strategic Management Journal, Vol. 26, pp. 47-74.

Doty, D. H., and Glick, W. H. (1994). 'Typologies as a Unique form of Theory Building: Toward Improved Understanding and Modeling'. Academy of Management Review, Vol. 19 No. 2, pp. 230-251.

Funnell, W., and Cooper, K. 1998. Public sector accounting and accountability in Australia, Sydney: UNSW Press.

Garrigos-Simon, F. J., Marques, D. P., and Narangajavana, Y. (2005). 'Competitive strategies and performance in Spanish hospitality firms'. International Journal of Contemporary Hospitality Management, Vol. 17 No. 1, pp. 23-38.

Goddard, A. (2005), 'Accounting and NPM in UK local government - contributions towards governance and accountability', Financial Accountability and Management, Vol. 21 No. 2, pp.191-218.

Hitt, M. A., and Ireland, R. D. (1985). 'Corporate distinctive competence, strategy, industry and performance'. Strategic Management Journal, Vol. 6, pp. 273-293.

Jaccard, J., Turrisi, R., and K., W. C. (1990). 'Interaction Effects in Multiple Regression', Newbury Park. CA: Sage.

Kald, M., Nilsson, F., and Rapp, B. (2000). 'On Strategy and Management Control: The Important of Classifying the Strategy of the Business'. British Journal of Management, Vol 11, pp. 197-212.

Lapsley, I. (1999), 'Accounting and the new public management: instruments of substantive efficiency or a rationalising modernity? ', Financial Accountability and Management, Vol. 15 No. 3, pp.201-7

Luke, B. (2008). 'Examining accountability dimensions in State-Owned Enterprises '. Proceedings of AFAANZ Conference, Sydney.

McDonough, D. D. (1998). 'Corporate Governance and Government Owed Corporation in Queensland'. Bond Law Review, Vol. 15 No. 10, 2, pp. 1-34.

McKinlay, P. (1998). 'State-owned enterprises and crown companies in New Zealand'. Public 
Administration and Development, Vol. 18, pp. 229-242.

Miles, R. E., and Snow, C. C. 1978. Organisational Strategy, Structure, and Process, New York: McGraw-Hill.

Miles, R. E., Snow, C. C., Meyer, A. D., and Coleman, H. R. J. (1978). 'Organisational Strategy, Structure, and Process'. Academy of Management Review, July, pp. 546-562.

NSW Government. (1994). Social Program Policy for NSW Government Trading Enterprises: NSW Government.

NSW Treasury. (2005). Commercial Policy Framework, Reporting and Monitoring Policy for Government Businesses: NSW Treasury, TPP 05-2, November 2005.

O'Regan, N., and Ghobadian, A. (2004). 'The Importance of Capabilities for Strategic Direction and Performance'. Management Decision, Vol. 42 No. 2, pp. 292-312.

Queensland Treasury. (1999). Community Service Obligations A Policy Framework: Queensland Treasury Department.

- 2006. Guidelines for the Preparation of Statements of Corporate Intent and Corporate Plans for Government Owned Corporations: Queensland Department of Treasury.

Seidman, H., (1954), 'The Government Corporation: Organization and Controls', Public Administration Review, Vol. 14 No. 3, pp. 183 -192.

Shoham, A., Evangelista, F., and Albaum, G. (2002). 'Strategic firm type and export performance'. International Marketing Review, Vol. 19 No. 3, pp. 236-258.

Sinclair, A. (1995). 'The chameleon of accountability: forms and discourses'. Accounting, Organisation and Society, Vol. 20 No. (2/3), pp. 219-237.

Slater, S. F., and Narver, J. C. (1993). 'Product-market Strategy and Performance: An Analysis of the Miles and Snow Strategy Types'. European Journal of Marketing, Vol. 27 No. 10 , pp. 33-51.

Smith, K. G., Guthrie, J. P., and Chen, M. (1986). 'Miles and Snow's Typology of Strategy, Organisational Size and Organisational Performance'. Academy of Management Proceeding, pp. 45-49.

Snow, C. C., and Hrebiniak, L. G. (1980). 'Strategy, Distinctive Competence, and Organisational Performance'. Administrative Science Quarterly, Vol. 25 June, pp. 317-336.

Song, M., Di Benedetto, A., and Nason, R. W. (2007). 'Capabilities and Financial Performance: The Moderating Effect of Strategic Type'. Journal of Academy Marketing Science, Vol. 35, pp. 18-34.

Stewart, J. D. (1984). 'The role of information in public accountability'. in Issues in Public Sector Accounting, Hopwood, A. and Tomkins, C. (eds). London: Phillip Allan.

Tasmania Treasury \& Finance. (1995). Treasury Instruction on Model Statement of Corporate 
Intent-GBE 06-41-01: Tasmania Treasury and Finance Department.

- 1996. Treasury Instruction on Community Service Obligations: GBE 13-114-04: Department of Treasury and Finance.

Othman, R., and Taylor, D.W., (2008), 'Management control systems and accountability in Malaysian local government', Working paper submitted to International Journal of Public Sector Management

Taylor, D. W., and Rosair, M. (2000). 'The effect of participating parties, the public and size on government department disclosures on annual reports'. Accounting, Accountability and Performance, Vol. 6 No. 1, pp. 77-97.

Thynne, I. (1998). 'Government companies as instruments of state action'. Public Administration and Development, Vol. 18, pp. 217-228.

Thynne, I., and Wettenhall, R. (2001). 'Public Enterprises: Many Faces, Much Questioning, New Challenges'. International Review of Public Administration, Vol. 6 No.1, pp. 1-9.

Uhrig, J. (2003). 'Review of Corporate Governance of Statutory Authorities and Office Holders'. Department of Communication, Information Technology and the Arts, Commonwealth of Australia. 2003.

Vorhies, D. W., and Harker, M. (2000). 'The Capabilities and Performance Advantage of Market-Driven Firms: An Empirical Investigation'. Australian Journal of Management, Vol. 25 No. 2, pp. 145-171.

Vorhies, D. W., Harker, M., and Roa, C. P. (1999). 'The Capabilities and Performance Advantages of Market-Driven Firms'. European Journal of Marketing, Vol. 33 No. 11/12, pp. 1171-1202.

Walker, O. C. J., Boyd, H. W. J., Mullins, J., and Larreche, J. C. (2003). 'Marketing Strategy: Planning and Implementation'. 4th ed. Homewood, IL: Irwin/McGraw-Hill.

Wettenhall, R. (1998). 'The rising popularity of government-owned company in Australia: problems and issues'. Public Administration and Development, Vol. 18, pp. 243-255.

Zahra, S. A., and Pearce, J. A. I. (1990). 'Research Evidence on the Miles-Snow Typology'. Journal of Management, Vol. 16 No.4, pp. 751-768. 


\section{Appendix}

Appendix 1. Extracts from the Questionnaire

\section{Accountability}

To what extent do you agree with the following statements about how well your organisation discharges its managerial and public accountability in the following ways?

\begin{tabular}{|c|c|c|c|c|c|c|}
\hline & $\begin{array}{l}\text { Strongly } \\
\text { Disagree }\end{array}$ & $\mid \begin{array}{l}\text { Some-wha } \\
\text { Disagree }\end{array}$ & $\begin{array}{l}\text { Slightly } \\
\text { Disagree }\end{array}$ & $\begin{array}{l}\text { Slightly } \\
\text { Agree }\end{array}$ & $\begin{array}{l}\text { Some what } \\
\text { Agree }\end{array}$ & $\begin{array}{l}\text { Strongly } \\
\text { Agree }\end{array}$ \\
\hline $\begin{array}{l}\text { 1. Highly responsible to ensure th } \\
\text { achievement of efficiency an } \\
\text { effectiveness outcomes }\end{array}$ & 1 & 2 & 3 & 4 & 5 & 6 \\
\hline $\begin{array}{l}\text { 2. Sets clear operating targets the } \\
\text { integrate with broader strategic goal }\end{array}$ & 1 & 2 & 3 & 4 & 5 & 6 \\
\hline $\begin{array}{l}\text { 3. Provide regular managemer } \\
\text { reports to 'oversight bodies' o } \\
\text { achievements and outcomes }\end{array}$ & 1 & 2 & 3 & 4 & 5 & 6 \\
\hline $\begin{array}{l}\text { 4. Monitor the quality of servic } \\
\text { delivery through the use of relevar } \\
\text { non-financial performance measures }\end{array}$ & 1 & 2 & 3 & 4 & 5 & 6 \\
\hline \begin{tabular}{|ll} 
5. Abide by quality assuranc \\
procedures, particularly those of \\
relevant \\
accrediting body
\end{tabular} & 1 & 2 & 3 & 4 & 5 & 6 \\
\hline $\begin{array}{l}\text { 6. Strong emphasis on providin } \\
\text { excellent service and responsivenes } \\
\text { to customer enquiries and complaint }\end{array}$ & 1 & 2 & 3 & 4 & 5 & 6 \\
\hline $\begin{array}{l}\text { 7. Consider customer and th } \\
\text { public's feedback into the provisio } \\
\text { of services/product and operation } \\
\text { the organization }\end{array}$ & 1 & 2 & 3 & 4 & 5 & 6 \\
\hline $\begin{array}{l}\text { 8. Provide considerable publi } \\
\text { information about the organization } \\
\text { services, projects and plans } \\
\text { customers and the public. }\end{array}$ & 1 & 2 & 3 & 4 & 5 & 6 \\
\hline
\end{tabular}




\section{Organisational Capabilities}

In relation to possessing the following types of general capabilities, how strong is your organisation?

\begin{tabular}{|l|l|l|l|l|l|l|}
\hline & $\begin{array}{l}\text { Very } \\
\text { Weak }\end{array}$ & $\begin{array}{l}\text { Some-whi } \\
\text { Weak }\end{array}$ & $\begin{array}{l}\text { Slightl } \\
\text { Weak }\end{array}$ & $\begin{array}{l}\text { Slight } \\
\text { Strong }\end{array}$ & $\begin{array}{l}\text { Some-wh } \\
\text { Strong }\end{array}$ & $\begin{array}{l}\text { Very } \\
\text { Stron }\end{array}$ \\
\hline $\begin{array}{l}\text { Financial Management capability (investments i } \\
\text { strategic projects/programs , cash managemen } \\
\text { financing decisions) }\end{array}$ & 2 & 3 & 4 & 5 & 6 \\
\hline $\begin{array}{l}\text { Cost control capability (cost efficiency i } \\
\text { service/product supply and delivery, tight budgeting) }\end{array}$ & 1 & 2 & 3 & 4 & 5 & 6 \\
\hline $\begin{array}{l}\text { Ability to monitor and predict technological change } \\
\text { in the industry (through research and cooperation wit } \\
\text { experts in the filed the organization able to determin } \\
\text { and forecast future technology trend affecting them) }\end{array}$ & 2 & 3 & 4 & 5 & 6 \\
\hline $\begin{array}{l}\text { Technology development (know how) and Innovatio } \\
\text { capability (capacity to develop new product/services } \\
\text { apply appropriate process technologies to produce ner } \\
\text { product to satisfy the market needs) }\end{array}$ & 2 & 3 & 4 & 5 & 6 \\
\hline $\begin{array}{l}\text { Product or Service Transformation processes (abilit } \\
\text { to turn resources into product or services efficientl } \\
\text { meet design specifications, developing and deliverin } \\
\text { benefits/value promised) }\end{array}$ & 2 & 3 & 4 & 5 & 6 \\
\hline $\begin{array}{l}\text { Customer-linking capability (creating and managin } \\
\text { durable customer relationships) }\end{array}$ & 1 & 2 & 3 & 4 & 5 & 6 \\
\hline $\begin{array}{l}\text { Capability to create durable relationships wit } \\
\text { suppliers (establishing and maintaining strong workin } \\
\text { relationships with suppliers and contractors) }\end{array}$ & 2 & 3 & 4 & 5 & 6 \\
\hline $\begin{array}{l}\text { Channel-bonding capability (creating durabl } \\
\text { relationships across channel members such as supplier } \\
\text { wholesalers and retailers) }\end{array}$ & 2 & 3 & 4 & 5 & 6 \\
\hline $\begin{array}{l}\text { Ability to retain customers (achieving high reper } \\
\text { business or retention rate of customers) }\end{array}$ & 1 & 2 & 3 & 4 & 5 & 6 \\
\hline $\begin{array}{l}\text { Market sensing capability (understand the targ } \\
\text { market(s) and competitors' capabilities) }\end{array}$ & 1 & 2 & 3 & 4 & 5 & 6 \\
\hline
\end{tabular}




\section{Strategic type}

Each group of statements below relates to an alternative type of strategic position for a profit-making organisation. Please indicate which set of statements (type 1, 2, 3 or 4) most closely fits your organisation.

Circle one number only that currently characterizes your organization's strategies.

\begin{tabular}{|c|c|}
\hline \begin{tabular}{|l} 
Strategic \\
Type
\end{tabular} & Statements about strategic position \\
\hline 1 & $\begin{array}{l}\text { - This type of organisation attempts to locate and maintain a secure niche in a } \\
\text { relatively stable product or service area. } \\
\text { - This organisation tends to offer a more limited range of products/services than its } \\
\text { competitors. } \\
\text { - This organisation protects its market domain by offering high quality, superior } \\
\text { services and low prices. } \\
\text { This organisation tends to ignore the industry changes that have no direct influence } \\
\text { on its market domain. }\end{array}$ \\
\hline 2 & $\begin{array}{l}\text { - This organisation typically operates within a broad product/ services market domain } \\
\text { that undergoes periodic redefinition. } \\
\text { - The organisation values being "first in" in new product/service and market areas } \\
\text { even if not all of these efforts prove to highly profitable. } \\
\text { - This organisation rapidly responds to area of opportunity, which leads to new round } \\
\text { of competitive action. } \\
\text { - This organisation may not maintain market strength in all areas it enters. }\end{array}$ \\
\hline 3 & $\begin{array}{l}\text { - This type of organisation attempts to maintain a stable, limited line of } \\
\text { product/services. } \\
\text { At the same time following a carefully selected set of the more promising ner } \\
\text { developments in the industry. } \\
\text { - This organisation is seldom "first in" with new products/ services, however by } \\
\text { carefully monitoring the actions of major competitors in areas compatible with its } \\
\text { stable product market base. } \\
\text { - This organisation can frequently be "second in" with a more cost-efficient product } \\
\text { or service. }\end{array}$ \\
\hline 4 & $\begin{array}{l}\text { - This type of organisation does not appear to have a consistent product or service } \\
\text { market orientation. } \\
\text { - This organisation is not as aggressive in maintaining established product/services } \\
\text { and markets as some of its competitors } \\
\text { - This organisation also not willing to take many risks as other competitors } \\
\text { - This organisation responds in the areas where it is forced by environmental } \\
\text { pressures. }\end{array}$ \\
\hline
\end{tabular}

